\title{
Shaeda Isani, Miguel Àngel Campos (eds.), Alicante Journal of English Studies
}

Alicante: Universidad de Alicante, 2015

\section{Géraldine Gadbin-George}

\section{(2) OpenEdition}

\section{Journals}

Electronic version

URL: http://journals.openedition.org/asp/4851

DOI: $10.4000 /$ asp. 4851

ISSN: 2108-6354

\section{Publisher}

Groupe d'étude et de recherche en anglais de spécialité

Printed version

Date of publication: 1 November 2016

Number of pages: 133-138

ISSN: 1246-8185

\section{Electronic reference}

Géraldine Gadbin-George, « Shaeda Isani, Miguel Àngel Campos (eds.), Alicante Journal of English Studies ", ASp [Online], 70 | 2016, Online since 01 November 2016, connection on 02 November 2020. URL : http://journals.openedition.org/asp/4851; DOI : https://doi.org/10.4000/asp.4851

This text was automatically generated on 2 November 2020

Tous droits réservés 


\section{Shaeda Isani, Miguel Àngel Campos (eds.), Alicante Journal of English}

\section{Studies}

Alicante: Universidad de Alicante, 2015

Géraldine Gadbin-George

\section{REFERENCES}

Isani, Shaeda \& Miguel Àngel Campos (eds.). 2015. Alicante Journal of English Studies. Special issue: Language and the Law, Alicante: Universidad de Alicante. 218 p. ISSN 0214-4808. 
1 This special issue of the Alicante Journal of English Studies, ${ }^{1}$ published in November 2015 by the Anglophone Studies Department of Alicante University and edited by Shaeda Isani and Miguel Àngel Campos, includes nine contributions on a range of interdisciplinary subjects relating to the Law and the English language. It is mostly written for legal English specialists (teachers and students alike) although its scope could extend to legal practitioners wishing to have a better understanding of the workings of the legal language.

The first contribution, by Maria José Àlvarez Faedo, focuses on the specialist

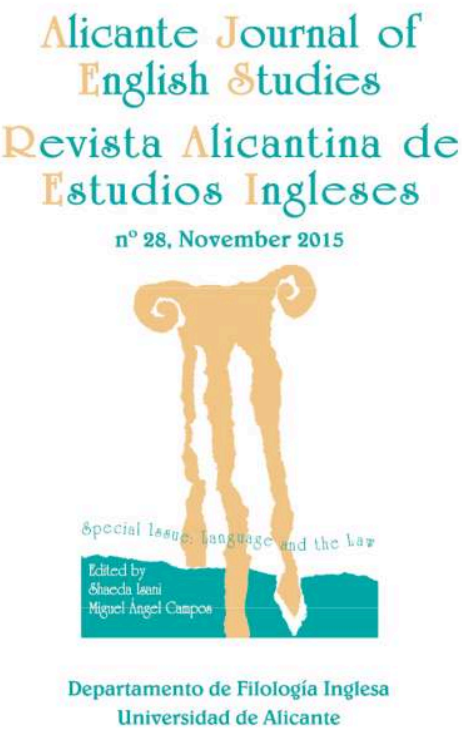
teaching of legal English to company law students. The author's choice of company law is justified by its role in international negotiations. An economic (as opposed to legal) definition of company law is given, based on the 2015 Business Dictionary found online on the WebFinance site (p. 16). The author believes that teaching textbooks tend to remain conservative, but that in the last fifteen years, lecturers have "adopted a broader perspective" and used other teaching means. She presents the results of a recent study carried out between October 2014 and March 2015, listing the main reference books used in law schools or law faculties in common law jurisdictions such as the United Kingdom (UK), the United States (US), Canada and Australia. After giving a brief outline of the "behaviourist", "cognitive" and "communicative" theories which underpin language teaching (pp. 2223), she does a comparative study of these publications, considering the number of chapters devoted to the teaching of company law, their respective contents and the types of exercises proposed to the most targeted students (pp. 23-30). The author emphasises the need for an "interactive interdisciplinary approach" (p. 30) and eventually suggests ways of complementing course book material, for example by resorting to Fiction à substrat professionnel - FASP (p. 31).

The second contribution, by Anne Brunon-Ernst, is an interesting pragmatic study of the English language used by four major online companies in their user agreements. Lay people (whether Anglophone or not) who wish to enter into an online contract are prompted to accept terms and conditions the meaning of which they may not fully grasp. We can interpret the author's comments as meaning that in some cases, agreeing to a company's terms and conditions without fully understanding them, because of the very complexity of the language used, may amount to undue influence on the part of the stronger party to the contract. A. Brunon-Ernst looks at linguistic markers "which impact on contract comprehension" (pp.39-49) and then moves on to suggesting textual and peri-textual alternatives to the way(s) in which some user agreements are designed, which, if they were adopted, would ensure that the weaker party to the contract gives an informed consent to the e-user agreement (pp. 49-54). Thanks to her linguistic approach, the author gives added value to the problems which may arise 
from the interdisciplinary debate between "law, psychology and behavioural economics" (p. 54).

In the third contribution, Marion Charret-Del Bove and Laurence Francoz-Terminal carry out a comparative and detailed study of British and American superior courts and of their decisions. After giving some information on the plain language movement and its evolution (pp.59-61), they explain that the US and the UK not only share a common language but also the same legal traditions. They also stress the differences between the ways both supreme courts operate which derive inter alia from the fact that as opposed to the US supreme court, its UK counterpart is not a constitutional court as such. They examine in detail the "discourse structure" (p. 64) and the "legal reasoning mechanisms" (p. 75) of their respective decisions, the ways in which the judges express their opinions and create precedents (pp. 64-79) before concluding that the UK and US systems are not "so common after all" (p. 79).

5 The fourth contribution by Maurizio Gotti is an analysis of the discourse used in China's arbitration law. The paper revolves around the study of The People's Republic of China Arbitration Law 1994 and this law is occasionally compared to the United Nations Model Law on International Commercial Arbitration in order to get a better understanding of the language issues which underpin the Chinese document. The choice of arbitration is particularly topical at a time of economic crisis when all countries try to find cheaper means of resolving disputes. The choice of China is relevant in view of the increase of commercial transactions between Western companies and corporations based in China. M Gotti demonstrates that if the formulation of the Chinese and United Nations arbitration laws is similar, the use of terms "that seem to have a specific meaning in the Chinese legal and political context" (p.88) coupled with "divergences in terms of clarity" (p. 98) raises potential concerns for Western companies who consider resorting to arbitration in China.

6 The fifth contribution is a compelling study of the social and cultural approach to teaching legal English through various means including fictional television series (now known as FASP), by Shaeda Isani and Sandrine Chapon. After examining the current epistemological trends in the English for Specific Purposes (ESP) tradition (pp. 104107), the authors focus on the practical pedagogic issues which must be addressed when teaching English in a legal cultural context. Based on various examples, ${ }^{2}$ they demonstrate that the specialised content of FASP is "on the whole, reliable" (p. 110) and provides a "higher density of specialised lexis than certain similar authentic texts" (p. 113). The authors also note an increase in students' motivation when FASP is offered as a pedagogic tool.

7 The sixth contribution looks into the language used in international legal texts. If the abstract indicates that three paradigmatic texts will be considered, only two are actually examined, the Rules issued by the London Court of International Arbitration (LCIA) and the Geneva Convention on the Contract for the International Carriage of Goods by Roads (CMR). No explanation is given as to why the third text (the insurance policies of the London Institute of Underwriters) does not appear in the article itself. The author, Marìa Àngeles Orts, purports to show that some legal texts are "instruments to wield power" and that there is a "possible equation between power and textual complexity" (p.118). In the context of the "globalization of legal transactions" (p. 120), she gives a summary of the two main schools of thinking relating to the complexity of legal language (the proponents and opponents of legalese) and 
explains her choice of the CMR and LCIA Rules, both documents having a "normative content" (p.121). She carries out a lexical analysis of both texts to identify the technical terms before separately examining the results obtained for the CMR (pp. 127130) and the LCIA Rules (p. 130-137). Then she considers speech act activity in both subcorpora to see how the exercise of power is reflected in both texts (pp. 137-140) before concluding that in spite of common features (due to their legal functions), the documents under study present very different communicative purposes.

In the seventh contribution, Catalina Riera carries out a particularly interesting study of the legal language used in two British statutes relating to the same field and having a similar scope, in order to examine whether the plain English movement has had a positive influence over the simplification of legalese. She chooses to study the Water Act 1973 (when the plain English movement was a budding one) and the Water Act 2014 (when plain English is now the norm). In her introduction, she reminds the reader that the simplification of the legal language is twofold: it covers "language and grammar" and "the techniques related to the design and structure of the document" (p. 149). She carries out a thorough analysis of the contents of both statutory documents, based on their respective structures, the use of modal auxiliaries, prepositional adverbs, passive sentences, complex prepositional phrases and nominalisation. Based on the results obtained, she concludes that the plain English movement has had a "significant impact" on the legal language, but that the process of simplification is a slow (but hopefully ongoing) one (p. 162).

9 The eighth contribution provides fascinating information on the evolution of the translation of Shakespeare's legal puns from English into Spanish from the 20th to the 21st century. The author, José Manuel Rodrìguez Herrera, explains that the Elizabethan era was a litigious one which provided opportunities to discuss legal matters at the theatre. He discusses Shakespeare's likely background in view of his perfect command of legal terminology and English law, saying that he may have been "an actual lawyer" or worked as a "law clerk" (p. 168). Bearing in mind the "law-worthy" and "stageworthy" dilemma (p.178) which translators must tackle when confronted with the profuse double-edged legal terms contained in Shakespeare's literature, he goes through the various Spanish translations of several legal puns over time (going as far back as the 18th century) and explains why the Spanish translation gives a faithful rendering of the message which Shakespeare intended to convey. He pays special attention to the contemporary works of Àngel Luis Pujante whom he believes has made Shakespeare's "legal punning accessible to theatre-goers and [...] scholars" alike (p. 178). We believe that this comprehensive study would turn any lay reader into a Shakespearean and legal translation fan.

10 The last contribution is a very modern approach of the evolution of plain language in the Anglophone legal sphere. ${ }^{3}$ First, Christopher Williams goes through the origins of the eponym movement without, however, going "over well-trodden grounds" (p. 184) before giving a number of pragmatic examples of "success stories" showing when, where and how legal language was made simpler in some fields (pp. 186-191). Most of these examples are concerned with "legislative drafting" and belong to the "public sphere" as opposed to the "private sphere of drafting" -such as contracts or willswhich presents "areas of resistance to plain language" (p. 191). The author believes that modern technologies like the Internet may be the way forward to get rid of legalese. Lay people are familiar with the Internet and now demand simpler legal documents. In 
2013, the UK sponsored a successful "Good law initiative" (p. 193). The author also suggests that judges be prompted to make their judgements more accessible before concluding that a lot has been done since the 1970s but more progress is necessary.

11 Despite its many qualities, some criticisms of the book can be made. Regarding the first contribution, we can only praise the author's efforts at providing a list of books which legal English teachers, specialising in company legal or corporate language, could resort to. However, it is a shame that the author's contribution starts with a financial/ economic definition of company law when so many (good) legal definitions exist. ${ }^{4}$ Likewise, her research is partly based on financial books -as opposed to legal onessuch as Ian Mackenzie's Professional English in Use: Finance (p. 23). This explains why only a small portion of them are devoted to company law and distorts the results of her research. Secondly, it would have been interesting to explore possible jurisdictional reasons explaining the different approaches taken by authors in the US and the UK: in other words, does the fact that US corporate law differs from company law in the UK affect the way company law is taught to students in those countries as well as teaching methods? Thirdly, and when presenting FASP as a way to complement the company legal language teaching based on textbooks, the author refers to a couple of films which only relate indirectly to company law. ${ }^{5}$

12 If the third contribution provides an extremely interesting comparative overview of the workings of the US and the UK higher judicial systems, one may regret that (British) William Blackstone should only be briefly mentioned (p.60) and (British) Edward Coke ${ }^{6}$ should not be mentioned at all despite the influence he still exerts over US judges. ${ }^{7}$ Moreover the focus is on "old" cases ${ }^{8}$ rather than recent ones which would have given a more modern approach to this study. Last but not least, we would have liked the authors to insist on the influence that the UK's membership of the European Union since 1973 (and until Brexit is actioned) has had on the way in which the UK supreme court operates. ${ }^{9}$

Regarding the fourth contribution, a couple of minor legal points need to be made: firstly, the assertion according to which "in Western legal culture" (p.96), it is not possible to mix litigation with alternative modes of dispute resolution (or various means of ADR which include arbitration, mediation and conciliation) is no longer totally accurate. As an example amongst others, in Britain, the Family and Children Act 2013 now makes it mandatory for divorcing couples to attend a Mediation Information Assessment Meeting (MIAM) before going to court. However and unlike the legislator, a court itself cannot (currently) constrain parties to resort to non-judicial ways of resolving a dispute. ${ }^{10}$ Likewise, we can regret the reference made by the author to the "common law 'adversarial' approach" as opposed to the "civil law 'inquisitorial' procedure" (p. 85). If this remains mostly true of the US procedural system, the implementation of the Civil Procedure Rules 1999 in England and Wales introduced an inquisitorial case management system (inspired from the French procedural system). But this does not affect the quality of this modern and topical contribution.

The idea underpinning the sixth contribution, i.e. studying the language used in two international texts to see whether the drafters used linguistic tools to exercise power over those who are subjected to those texts, is of interest. However this entails that the texts compared are comparable, which implies that they are of a similar nature. Unfortunately this is not the case here and the results of the research are consequently distorted: the CMR document is a document setting out rules governing the carriage of 
goods whereas the LCIA is a set of rules governing the non-judicial resolution of disputes. The choice of texts made by the author is therefore the wrong one, as is the choice of the keywords for the abstract. Incidentally, the abstract indicated that the Lloyds's insurance policies would be examined in her contribution but this is not the case.

Regarding the last contribution, we particularly enjoyed the fact that "old" references like Tiersma (1999) were only briefly mentioned, the research focusing on the modern approach of the plain language movement. However, and except for one reference to the potential role of judges (p.193), we regretted that litigation was implicitly excluded from the scope of the author's research. Substantial progress has already been achieved with simplifying the language of judgements and pleadings and we believe this was worth mentioning. ${ }^{11}$

As a general conclusion and in spite of the few criticisms made above, this special issue of the Alicante Journal of English Studies casts an interesting and innovative light over the relationship between law and the language of the law, covering a range of issues which complement each other. I would therefore recommend it to legal English specialists and non-Anglophone lawyers alike if the latter have an interest in understanding the workings of the English legal language.

\section{BIBLIOGRAPHY}

GADBIN-GEORGE, Géraldine. 2010. “The Woolf reform of civil procedure: A possible end to legalese?”. LSP Journal 1/2. Retrieved from <http://lsp.cbs.dk> on 10 September 2016.

GARNER, Bryan A. (ed.). 2014. Black's Law Dictionary (10 th ed.). Eagan: West Publishing.

TIERSMA, Peter M. 1999. Legal Language. Chicago: University of Chicago Press.

\section{NOTES}

1. <http://rua.ua.es/dspace/handle/10045/54175>.

2. However, we regret that the US series, Better Call Saul, is not mentioned amongst the examples given.

3. The author omits to say that this has already been achieved in England and Wales since the Civil Procedure Rules 1999 came into force.

4. See Garner (2014).

5. For example, both Erin Brockovitch and A Civil Action relate to tortious claims made against large-size companies. The corporate issues raised are only ancillary to the liability issues.

6. Who presided over the committee which drafted the Petition of Right 1628.

7. See, for example, Department of Transportation v. Association of American Railroads 575 U. S. (2015); Kerry, Secretary of State, et al. v. Din 576 U.S. (2015); or Stoneridge Investment Partners LLC v. ScientificAtlanta, Inc 443 F. 3d 987 (2008). 
8. Amongst many other examples, see Donoghue v. Stevenson [1932] UKHL 100; or Roe v. Wade 410 U.S. 113 (1973).

9. The part played by 'judge-made' law (i.e. the creation of precedents) has decreased as the judicial interpretation of statutory provisions has increased.

10. As confirmed in Halsey v. Milton Keynes General NHS Trust, [2004] EWCA (Civ) 576 (Eng.).

11. For an example pertaining to England and Wales, see Gadbin-George (2010).

\section{AUTHORS}

\section{GÉRALDINE GADBIN-GEORGE}

Université Panthéon-Assas, geraldine.george@gmail.com 